\title{
Implementation of Bacterial Detection Methods into Blood Donor Screening - Overview of Different Technologies
}

\author{
Michael Schmidt Walid Sireis Erhard Seifried
}

German Red Cross, Institute for Transfusion Medicine and Immunohaematology, Johann Wolfgang Goethe University, Frankfurt/M., Germany

\begin{abstract}
Keywords
Bacterial detection systems - Culture tests .

Rapid detection systems - Bedside tests
\end{abstract}

\section{Summary}

Background: Through the implementation of modern technology, such as nucleic acid testing, over the last two decades, blood safety has improved considerably in that the risk of viral infection is less than 1 in a million blood transfusions. By contrast, the residual risk of transfusion-associated bacterial infection is stable at approximately 1 in 2,000 to 1 in 3,000 in platelets. To improve blood safety with regard to bacterial infections, many countries have implemented bacterial screening methods as part of their blood donor screening programmes. Methods: Bacterial detection methods are clustered into three groups: i) culture methods in combination with the 'negative-to-date' concept, ii) rapid detection systems with a late sample collection, and iii) bedside screening tests. Results: The culture methods are convincing because of their very high analytical sensitivity. Nevertheless, false-negative culture results and subsequent fatalities were reported in several countries. Rapid bacterial systems are characterised as having short testing time but reduced sensitivity. Sample errors are prevented by late sample collection. Finally, bedside tests reduce the risk for sample errors to a minimum, but testing outside of blood donation services may have risks for general testing failures. Conclusion: Bacterial screening of blood products, especially platelets, can be performed using a broad range of technologies. Each system exhibits advantages and disadvantages and offers only a temporary solution until a general pathogen inactivation technology is available for all blood components.

\author{
Schlüsselwörter \\ Bakterielle Screening-Methoden · Kulturtests . \\ Schnellnachweissysteme · "Bedside»-Tests
}

\section{Zusammenfassung}

Hintergrund: Die Sicherheit der Blutprodukte wurde in den letzten Jahren deutlich verbessert. Durch die Einführung von Nukleinsäureamplifikationstests konnte das virale Restinfektionsrisiko auf kleiner 1:1 Million reduziert werden. Dem gegenüber steht ein bakterielles Übertragungsrisiko von zirka 1 in 2000 bis 1 in 3000 bei Thrombozytenkonzentraten. Um die Sicherheit der Blutprodukte in Bezug auf bakterielle Infektionen zu erhöhen, haben viele Länder bakterielle Screening-Methoden eingeführt. Methoden: Bakterielle Screening-Methoden werden in folgende Gruppen klassifiziert: a) Kulturmethoden mit einer Freigabe als "negative-to-date", b) bakterielle Schnelltestmethoden, c) "Bedside»-Nachweisverfahren. Ergebnisse: Kulturmethoden überzeugen durch eine sehr hohe analytische Sensitivität. Trotzdem wurden in verschiedenen Ländern schwerwiegende bakterielle Übertragungen aufgrund von falsch negativen Ergebnissen mit Kulturmethoden berichtet. Bakterielle Schnelltestmethoden werden durch eine kurze Testzeit, jedoch auch durch eine reduzierte Sensitivität charakterisiert. Das Risiko für Probenfehler ist aufgrund der späten Probenziehung reduziert. Die «Bedside»-Tests reduzieren dieses Risiko auf ein Minimum, haben jedoch möglicherweise ein höheres Risiko für Testfehler, da die Testung nicht in einem Blutspendedienst erfolgen kann. Schlussfolgerung: Das bakterielle Screening von Blutkomponenten, insbesondere von Thrombozytenkonzentraten, kann mit vielen Technologien erfolgen. Jede Methode hat sowohl Vorteile als auch Nachteile und stellt somit eine Zwischenlösung dar, bis eine generelle Pathogeninaktivierungstechnologie für alle Blutkomponenten verfügbar ist.

\section{KARGER}

Fax +497614520714

Information@Karger.de

www.karger.com (c) 2011 S. Karger GmbH, Freiburg

Accessible online at:

www.karger.com/tmh
PD Dr. med. Michael Schmidt

German Red Cross, Institute for Transfusion Medicine and Immunohaematology Johann Wolfgang Goethe University

Sandhofstraße 1, 60528 Frankfurt, Germany

Tel. +49 69 6782-367, Fax -4962

mschmidt@blutspende.de 


\section{Introduction}

Although patients are still afraid of transfusion-transmitted viral infections, especially HIV, improvements in blood safety (e.g., improved donor selection programmes, introduction of 3rd- and 4th-generation antibody tests, and implementation of nucleic acid technologies in blood donor screening) has diminished the residual risk to a minimum. Based on 30 million mini-pool nucleic acid testing (NAT) investigations, Hourfar et al. [1] calculated the residual transfusion-transmitted risk for viral infections to be 1:10.88 million and 1:4.3 million for HCV and HIV-1, respectively. These risks are close to zero, with a diagnostic window period of 3-6 days for $\mathrm{HCV}$ and 6-8 days for HIV-1, and are far below the risk for bacterial transmission. Therefore, bacterial contamination of blood products represents an ongoing challenge in the area of transfusion medicine. Haemovigilance systems, such as the Serious Hazards of Transfusion (SHOT) study from the UK [2], have demonstrated that the major cause of morbidity and mortality are the transfusion-transmitted infections (TTI), identified as bacterial infections (data collected between 1996 and 2009; major morbidity in 28 out of 51 cases; death caused by TTI in 11 out of 15 cases). The Paul Ehrlich Institute in Germany reported 5 transfusion transmitted fatalities due to bacterial transmission by platelet concentrates between 1997 and 2007 [3, 4]. In 4 out of 5 cases, the platelet concentrates were transfused on day 5 after donation. These data, which are representative for world-wide results, contrast the perceptions of many physicians. Based on these data, the German authorities in 2008 reduced the maximum shelf life of platelets from 5 days after blood donation to 4 days. Potentially contaminated blood components (e.g., platelet concentrates stored at room temperature) are one major risk. Furthermore, patients are at additional risk for bacterial infections due to catheters, contact with staff; and non-compliance of hygiene standards. The patient's immunological status is also a critical and important factor for susceptibility to bacterial infections. Immunosuppressed patients undergoing chemotherapy or gamma irradiation are at a greater risk for bacterial infections compared with the normal population. Bacteria can be classified in a number of different ways: as Gram-negative and Gram-positive bacteria, as aerobic and anaerobic bacteria due to the major metabolic pathway, or as hospital and environmental bacteria. The latter classification is important because hospitals are at risk for developing multidrug-resistant bacteria, which represent a major challenge for efficient treatment. The major source for bacterial contamination of blood components is physiological donor skin flora. To reduce the bacterial contamination risk of blood components, all critical steps such as donor selection, donor arm disinfection, diversion of the initial blood flow, manufacturing processes of blood components, bacterial screening methods, and pathogen-reduction technologies should be analysed and optimised. This paper gives an over- view of bacterial screening methods and their efficacy as well as of new strategies to improve blood safety with regard to bacterial contamination [5-7].

\section{Material and Methods}

\section{Bacterial Screening in Platelet Concentrates}

The ideal screening test should have an extremely high diagnostic sensitivity, a short test time, and a high clinical efficiency. All of the described test systems were evaluated with regard to these criteria. Bacterial screening systems can currently be divided into culture assays and rapid detection systems. Based on the published data in the literature, methods can be classified into the following three categories:

- Culture methods in combination with a 'negative-to-date' concept

- Rapid detection methods with a late sample collection

- Bedside tests for screening immediately before transfusion at the hospitals.

Culture Methods in Combination with a 'Negative-to-Date' Concept In 2007, the International Society of Blood Transfusion (ISBT) held an international forum [8], which reported on bacterial detection in platelet concentrates in 12 countries. Eight of these 12 countries used BacT/ ALERT (bioMérieux, Nürtingen, Germany). A defined volume of the product sample $(4-10 \mathrm{ml})$ is added to a culture bottle under sterile conditions containing specific growth medium. All of the inoculated bottles are incubated for up to 7 days at $35-37^{\circ} \mathrm{C}$ in an incubation unit of the BacT/ AELRT system. Bacteria growth changes the colour of a gas-permeable sensor at the bottom of the culture bottle from grey to yellow. The analytical sensitivity was determined in several studies and was found to be less than 1 colony forming unit (CFU)/ml [9-14]. The culture methods were used in combination with a 'negative-to-date' concept [15-18]. All of the samples were collected from the platelet concentrates within $24 \mathrm{~h}$ after donation. The platelet concentrates with a negative diagnostic status were released without any delay. If the result status changed from negative to reactive, physicians were informed immediately, and products were recalled. If platelet concentrates were already transfused, physicians took special care of their patients due to suspected bacterial infection. Additional culture systems, such as the Bactec ${ }^{\mathrm{TM}}$ system (BD Diagnostics - Diagnostic Systems, Becton Dickinson GmbH, Heidelberg, Germany), were also available on the market and were implemented in some of the blood donor services with comparable data [19-21]. The Pall eBDS system [19, 22-24] (Pall GmbH, Dreieich, Germany) must be grouped between the culture methods and the rapid detection methods. In this system, a small sample volume is incubated in special growth medium for $24 \mathrm{~h}$. Thereafter, the $\mathrm{O}_{2}$ consumption is analysed. The final results are available within $24 \mathrm{~h}$. Based on this strategy, only bacteria that use aerobic metabolism can be detected, which confers some risk for false-negative screening results.

\section{Rapid Detection Methods in Combination with a Late Sample Collection}

\section{Bacterial Screening in Platelets by NAT}

In addition to the established culture methods described above, several rapid detection systems for bacterial screening of blood components have been developed and investigated in spiking studies. Several investigators focused on NAT systems [25-28]. To develop generic polymerase chain reaction (PCR) systems, investigators used nucleic acid sequences of bacterial ribosomes (16s and 23s), which are conserved in certain regions of eubacteria, as potential targets. Unfortunately, bacteria (e.g., Thermus aquaticus or Escherichia coli) are the source of the enzymes that are used for PCR amplification, which are therefore not free of contamination with bacterial genome fragments. Therefore, non-specific signals that arise during the PCR might reduce the analytical sensitivity of this system. 


\section{Bacterial Screening in Platelets by FACS Methods}

Another approach is the detection of bacteria in platelet concentrates by flow cytometry. A method based on reagents from BD Biosciences (Becton Dickinson GmbH, Heidelberg, Germany) has been evaluated for the investigation of platelet concentrates [29]. First, a 50- $\mu$ l volume of platelet concentrates is added to a BD True Count tube with a defined number of fluorescent beads. Second, $450 \mu$ l of the incubation solution that contains thiazole orange as fluorescent dye is added to label the bacteria. The detection method is rapid, such that the total time for the preparation and FACS analysis is only $5 \mathrm{~min}$ and can be fully automated. The analytical sensitivity can be improved by a pre-incubation of the sample volume in bacterial growth media under optimal conditions [30].

Furthermore, a solid-phase cytometry system has been developed by Hemosystems (Marseille, France). Sample volumes from three platelet products are pooled into one sample pouch, stained with the fluorescent dye picogreen, filtered on a black membrane, and scanned by a solidphase cytometre that is connected to an argon-laser epifluorescence microscope. Bacterial detection is feasible in platelet concentrates [31-33] and red cell concentrates [34] and has an analytical sensitivity of 100 to 1,000 CFU/ml. However, differentiating between bacteria and other labelled substances is difficult. Therefore, the system is no longer available on the market.

Dreier et al. [35] described a novel system named Bactiflow (Chemunex, Ivry-Sur-Seine, France), which was developed for the food industry to detect bacterially contaminated meat. The staining dye is released by bacterial esterases in this system. Therefore, the system screens for live bacteria by FACS. The analytical sensitivity is approximately $500 \mathrm{CFU} / \mathrm{ml}$.

Motoyama et al. [36] described a new bacterial detection system based on a fluorescent indicator for esterase activity. Bacterial cells that are trapped on a filter are automatically discriminated from other particles or platelet debris and counted by a bioimaging system. In the first study, the analytical sensitivity was demonstrated for 14 bacterial strains to be 20 $\mathrm{CFU} / \mathrm{ml}$. The entire process takes approximately $45 \mathrm{~min}$. The discrimination between bacteria and particles is performed in a fully automated manner and is independent of the investigator.

\section{Bacterial Detection by ELISA}

Another new approach was presented by Fleming et al. [37] at the AABB in 2008. This approach uses an automated enzyme-linked immunosorbent assay (ELISA). The system is capable of high-throughput analysis and can test up to 180 samples in approximately $3 \mathrm{~h}$. The capture technology is based on the use of a high-affinity pattern recognition protein (PRP) that binds to a component of the bacterial cell wall. The analytical sensitivity for this assay is approximately $10^{4} \mathrm{CFU} / \mathrm{ml}$.

\section{Bacterial Detection with Experimental Approaches}

Norton et al. [37] described a bacterial detection system that uses ATP luminometry. $1 \mathrm{ml}$ of platelet concentrate is incubated with $100 \mu \mathrm{l}$ of lysis buffer. The lysis takes $5 \mathrm{~min}$. The ATP level after lysis is compared with the ATP background level at the beginning of the investigation. The analytical sensitivity was demonstrated to be $10^{4} \mathrm{CFU} / \mathrm{ml}$.

\section{Bedside Tests}

Further experimental and clinical validation studies are needed to assess the benefit of these methods. The Pan Genera Detection technology [38, 39] (Verax Biomedical Inc., Worcester, MA, USA) targets the conserved antigens, lipopolysaccharide and lipoteichoic acid, that are present on Gramnegative and Gram-positive bacteria, respectively [40]. These antigens are present on bacterial cells at high copy numbers ( $>200,000$ copies/cell). Preliminary studies demonstrated an analytical sensitivity of approximately $10^{3}$ $\mathrm{CFU} / \mathrm{ml}$. The handling time is only $20 \mathrm{~min}$. Therefore, this system might be feasible as a bedside test that can be performed directly before transfusion or at the blood transfusion unit before release of platelet concentrates.

A new non-invasive continuous $\mathrm{O}_{2}$ measurement system was presented at the AABB in 2008 in Montreal [37]. Special testing probes inte- grated into the platelet bag monitor the $\mathrm{O}_{2}$ concentration inside the platelet concentrates. The investigators demonstrated a correlation between an increase in bacterial concentration and a decrease in $\mathrm{O}_{2}$ concentration. Analytical sensitivity was between $10^{3}$ and $10^{6} \mathrm{CFU} / \mathrm{ml}$. This technology can be combined with radiofrequency identification [41-44] (RFID) to improve blood safety by avoiding errors in identification of patients. $\mathrm{O}_{2}$ probes can monitor data until the transfusion begins. Despite reduced analytical sensitivity associated with this method, it might be clinically efficient because of the chance to detect contaminated platelets immediately before transfusion.

\section{Results}

\section{Culture Methods}

The BacT/ALERT culture system is widely used to screen platelet concentrates for bacterial contamination. Te Boekhorst et al. [45] reported that 203 out of 28,104 (0.72\%) cases initially tested positive using this system. The bacterial strain could be identified in 184 out of 203 (90.6\%) samples. Unfortunately, in 113 out of 203 (55.7\%) cases, the contaminated platelet concentrates had already been transfused prior to the positive signal reported by the Bact/ALERT. In contrast, Eder et al. [46] reported that only 186 out of 1,004,206 $(0,019 \%)$ apheresis platelet samples gave confirmed positive results. Transfusion of all but one of the associated blood components was prevented. Differences between these two studies might be explained by their different screening protocols (the use of pre-donation sampling versus non-pre-donation sampling; a sample volume of $4 \mathrm{ml}$ versus 5-10 ml; detection with aerobic bottles only versus aerobic and anaerobic bottles; and different definitions of test results). With a 'negative-to-date' strategy, most platelet units (55\%) had already been issued at the time of the first positive culture. Te Boekhorst et al. [45] and Schrezenmeier et al. [18] screened all of the platelets with aerobic and anaerobic bottles. Propionibacterium acnes was identified in anaerobic bottles only in 20 out of 37 confirmed positive samples. This bacterial strain is slow growing, which might explain the prolonged detection time that was not recognised in the US study [47].

Nevertheless, culture methods such as the BacT/ALERT systems can also be implemented with a different approach, including the semi-rapid detection method with a maximum incubation time of $12 \mathrm{~h}$. Sireis et al. [48] reported on a spiking study with sample collection on day 3, 4 and 5 after blood donation. Platelet concentrates were spiked with a very low bacterial concentration $(0.03 \mathrm{CFU} / \mathrm{ml})$ to mimic real-life conditions. The maximum culture time was $12 \mathrm{~h}$ for Streptococcus pyogenes. Data from Sireis et al. [48] demonstrated that the incubation time can be shortened for culture systems by screening sample volumes from day 3 or later after donation. This strategy might reduce the risk for sample errors in culture systems.

\section{Rapid Bacterial Detection Methods}

Feng et al. [49] described one of the first NAT assays for the detection of Yersinia enterocolitica in blood; the assay had an 
analytical sensitivity of 5,000 CFU/ml. This sensitivity is not acceptable for blood screening tests because donors with 2.5 million bacteria in $500 \mathrm{ml}$ of blood $(5,000 \mathrm{CFU} \times 500 \mathrm{ml})$ would be excluded due to illness. Newly developed primers and probes with fluorescent molecules at the 5' and $3^{\prime}$ ends allow detection with improved sensitivity in a closed system compared with conventional PCR and detection via agarose gel electrophoresis. This real-time PCR system for bacterial detection was described by Nadkarni et al. [26] and has an analytical sensitivity between 30 and $100 \mathrm{CFU} / \mathrm{ml}$. However, this system is still unable to overcome, in principle, the problem of non-specific signals. Mohammadi et al. [50] solved this challenge by pre-treating the PCR mixture with the restriction enzyme Sau3AI. Prior to the addition of the template DNA, the PCR mixture was subjected to digestion with the enzyme Sau3AI, which improves the detection limit to $1 \mathrm{CFU}$ equivalent/PCR reaction. Another possible solution includes an additional filtration step for all NAT reagents with GenElute Plasmid Maxiprep binding columns [51]. Both of the methods can be combined to optimise the results. Other investigators attempted to decontaminate PCR materials by UV irradiation, 8-methoxypsoralen treatment, DNase treatment, or combinations of these methods [51-55]. However, most of these methods also reduce analytical sensitivity. Therefore, some investigators recommend a reduction in the number of PCR cycles as the most effective and reproducible way to avoid false-positive results $[26,53]$. Real-time NAT is a powerful tool for the clinical diagnosis of bacterial contamination in blood products. The extraction method can be fully automated $[56,57]$ and barcode controlled to perform the screening of a large number of samples. DNA/RNA extraction can be completed using material from platelet concentrates and whole blood to include all blood components into the bacterial screening process. The analytical sensitivity is currently between 10 and $50 \mathrm{CFU} / \mathrm{ml}$, and thus, this method is slightly less sensitive compared to culture methods. The total screening time for NAT systems (extraction and amplification) is approximately $4 \mathrm{~h}$. Therefore, these methods offer opportunities for late sampling, which can overcome sampling errors. Further field studies are needed to definitively show the applicability of NAT for routine screening.

The analytical sensitivity of FACS technologies was determined to be between $10^{3}$ and $10^{5} \mathrm{CFU} / \mathrm{ml}[29,58]$. The pre-incubation is performed in a special bacterial growth medium. As described by Schmidt et al. [30, 54], this incubation can improve the analytical sensitivity to $10 \mathrm{CFU} / \mathrm{ml}$ depending on the pre-incubation time and the bacterial strain.

Unfortunately, the complete lysis buffer and staining dye from BD Biosciences as well as the Scansystem ${ }^{\mathrm{TM}}$ (Hemosystems) method are no longer available on the market. However, a new FACS approach called Bactiflow, which was developed for the food industry, was adopted by Dreier and coworkers for bacterial detection in platelets. Vollmer et al. [59] presented data on 14 months of bacterial detection in platelets.
Out of 472 screened platelet concentrates, 1 sample was contaminated with Staphylococcus aureus and was diagnosed as positive by both, Bactiflow and BacT/ALERT. Eight samples were falsely positive, and 2 platelet concentrates showed falsenegative results by Bactiflow. In both platelet concentrates, $P$. acnes were detected after 7 days of culture by BacT/ALERT.

\section{Bedside Tests}

A sample collection immediately before transfusion provides the best opportunity to avoid false-negative screening results with regard to sample errors. Two different technologies are available for this purpose. The Pan Genera Detection Immunoassay (Verax Biomedical Inc) is able to detect Gram-positive and Gram-negative bacterial strains. To use the system, limited medical devices such as a table centrifuge, a vortex system, and hand pipettes are needed. All of the working steps can be performed in a laboratory space on the ward within a total test time of less than $30 \mathrm{~min}$. As reported by Yomtovian et al. [60,61], the specificity of this method is sufficient, but the analytical sensitivity is in a range between $10^{3}$ and $10^{5} \mathrm{CFU} / \mathrm{ml}$. This range might be acceptable if platelet concentrates will be transfused immediately after testing. Therefore, any additional increase in bacterial concentration between testing and transfusion can be excluded.

Schmidt et al. [62] described another approach by real-time monitoring of $\mathrm{O}_{2}$ concentrations within platelet liquids. $\mathrm{Re}-$ sults can be stored on a RFID chip. If the $\mathrm{O}_{2}$ concentration is below a critical threshold, platelet concentrates seems to be contaminated with bacteria and are not used for transfusions. The analytical sensitivity is comparable with the Verax system, but hospital testing procedures will be reduced to reading data on the RFID chip. A disadvantage of this approach is that only aerobic bacteria consume $\mathrm{O}_{2}$; therefore, only these pathogens will be detected using this system.

\section{Discussion}

In several countries, transfusion-transmitted bacterial infection with a fatal clinical outcome and false-negative screening results have been reported ( 2 cases with Bacillus cereus in the Netherlands, 1 case with Klebsiella pneumoniae in Germany, and 3 cases with Staphylococcus spp. in the USA). Fatalities in the USA and Germany occurred after transfusion on day 5 after blood donation. A small sample of the contaminated platelet product (in the German case) was retested using BacT/ALERT to exclude the possibility of a general failure in the screening assay. All of the samples tested positive in these subsequent tests, and all of these cases were examples for sampling errors. Based on low bacterial concentrations in final platelet concentrates (estimated between 1 and $10 \mathrm{CFU} /$ bag), there is a risk that the sample volume processed in culture systems did not contain bacterial colonies, although platelet concentrates are still contaminated. Within platelet 
Fig. 1. Bacterial screening strategies. Bacterial screening in platelets can be performed by: A Culture methods with a 'negative-to-date' concept. Although this system has a high sensitivity, most platelet concentrates are already transfused before a reactive signal occurs.

B Rapid bacterial detection methods with a late sample collection. This strategy includes a release of platelet concentrates on day 1 and 2 without bacterial screening and on day 3 to 5 with bacterial screening. Several methods are possible (NAT or FACS systems). The analytical sensitivity is slightly reduced.

C Bedside tests immediately before transfusion. This strategy includes $100 \%$ bacterial testing before transfusion. The performance is transferred from the blood establishments to

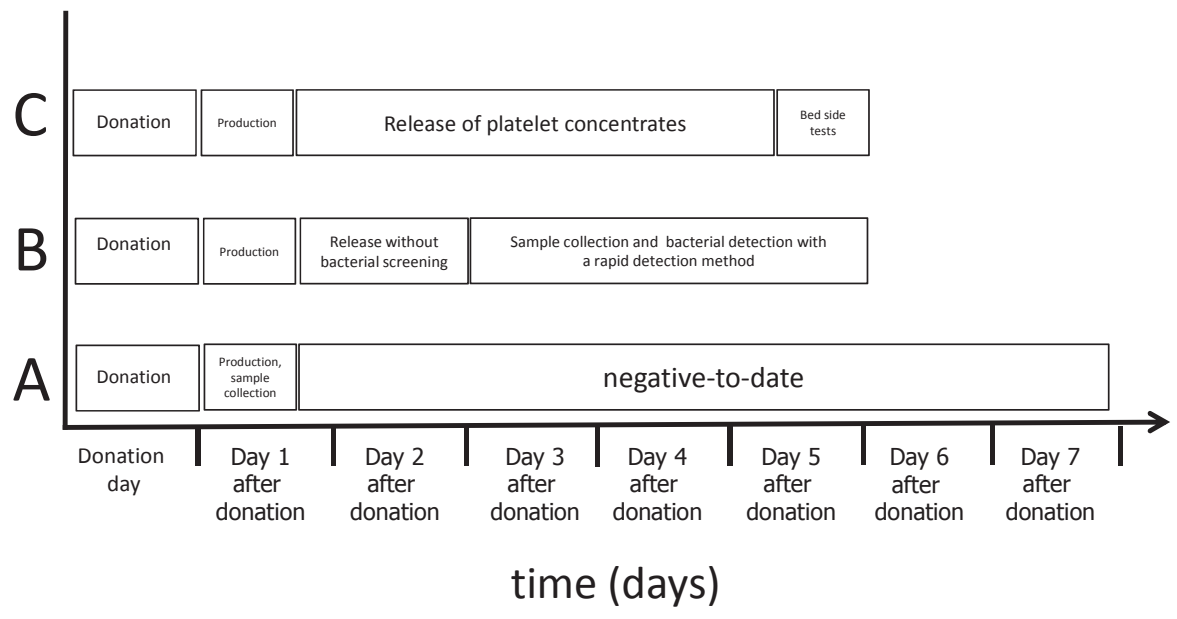

hospitals. The risk for sample errors will be reduced to a minimum, but the analytical sensitivity will be lower than for strategies A and B.

concentrates shelf life, low concentrations of bacteria can grow up and might cause severe septic reactions after transfusion. Benefits of culture systems are high analytical sensitivities, complete barcode-controlled systems, and fully automated working processes. Disadvantages of these methods are risks for sampling errors and reduced clinical efficiency, especially for slow-growing bacteria like $P$. acnes.

As reported by Silva et al. [63], approximately $10 \%$ of apheresis platelets in the USA are screened by the enhanced bacterial detection system (eBDS). The detection device measures the oxygen concentration in the air above the sample. The sampling pouch is connected by sterile docking to the $\mathrm{PC}$, and samples are incubated for $18-24 \mathrm{~h}$ at $35^{\circ} \mathrm{C}$ on a horizontal agitator. Thereafter, the $\mathrm{O}_{2}$ level is determined in the headspace. All of the results with an $\mathrm{O}_{2}$ concentration below a threshold of $9.4 \%$ are interpreted as positive. The analytical sensitivity has been investigated in several studies [22-24, 64] and is comparable to the BacT/ALERT sensitivity with 1 $\mathrm{CFU} / \mathrm{ml}$. The advantage of this bacterial detection assay is that it is a barcode-controlled, closed system to avoid secondary contamination, and it has a fixed detection time of $24 \mathrm{~h}$ after sample collection. Platelets can be released if a definite test result is observed. Recalls are not necessary. However, the risk for sampling errors is the same as that for BacT/ALERT.

As demonstrated by Schrezenmeier et al. and Schmidt et al. [18, 22], fatalities have also been reported even after blood products were screened using eBDS. Another disadvantage is that anaerobic bacterial strains cannot be detected. Unfortunately, only a few bacterial strains exclusively use an aerobic or anaerobic metabolism. Most bacterial strains possess both metabolic options, with facultative aerobic or anaerobic metabolism. Therefore, false-negative results can be obtained if bacterial strains switch from aerobic to anaerobic metabolism.

Fatalities from transfusion reactions have been observed solely with platelet concentrates that were transfused at the end of shelf life. The initial risk of sampling errors due to culture methods can be overcome with a rapid screening system on days 3-5 after donation. Therefore, a rapid detection system, such as NAT or the FACS systems, may be implemented into routine blood donor screening. Within the last decade, a real-time NAT system has been developed and improved to avoid false-negative unspecific screening results. Experimental data from different groups demonstrated that the analytical sensitivity (approximately $100-1,000 \mathrm{CFU} / \mathrm{ml}$ ) as well as the diagnostic specificity is comparable between NAT systems and modern FACS systems including the Bactiflow testing procedure. Implementation of rapid bacterial screening tests into screening should be combined with a sample collection on days 3,4 , or 5 after blood donation. Within this screening procedure, platelet concentrates can be released on days 1 and 2 after donation without bacterial screening and on days 3-5 with bacterial testing. This strategy includes two quality levels of platelet concentrates: i) products without bacterial screening and ii) products with testing. Based on published data, release of platelets on day 1 and 2 is unlikely to cause bacterial fatalities. Therefore, the screening procedure described by Dreier et al. [35] may be an alternative to bacterial screening with culture systems based on the 'negative-to-date' concept. All three options (i) bacterial screening by culture systems; ii) rapid bacterial screening with late sample collection; iii) bedside testing) are presented in figure 1 . In principle, platelet shelf life can be extended to a maximum of 7 days by implementation of bacterial screening methods, but only a few countries accept this approach. The majority of countries reduced the maximum platelet shelf life to 5 days due to decline of the risk for septic reactions as well as to avoid transfusion of platelet concentrates with reduced function.

Bedside tests are also considered as rapid detection assays. The major benefit of these systems is the reduction of sample errors to a minimum. Unfortunately, the analytical sensitivity of these tests is lower than that of other rapid tests or culture 
Bacterial detection methods

\begin{tabular}{|c|c|c|c|c|c|}
\hline \multicolumn{2}{|c|}{ A: Culture methods } & \multicolumn{2}{|c|}{ B: Rapid methods } & \multicolumn{2}{|c|}{ C: Bedside tests } \\
\hline Advantage & Disadvantage & Advantage & Disadvantage & Advantage & Disadvantage \\
\hline (8) Good sensitivity & (6) Long test time & (3) Short test time & : Reduced sensitivity & (9) Short test time & (2) Reduced sensitivity \\
\hline $\begin{array}{l}\text { (C) Easy test procedure } \\
\text { (3) Automated analysis }\end{array}$ & $\begin{array}{l}\text { (2) Recalls necessary } \\
\text { Limited clinical } \\
\text { efficiency } \\
\text { 2 Risk on sampling } \\
\text { errors }\end{array}$ & $\begin{array}{l}\text { (3) Automated testing } \\
\text { possible } \\
\text { (5) No re-calls } \\
\text { (5) High clinical } \\
\text { efficiency } \\
\text { (5) Reduced risk for } \\
\text { sampling errors }\end{array}$ & $\begin{array}{l}\text { Release without } \\
\text { testing for the } \\
\text { first two days }\end{array}$ & $\begin{array}{l}\text { (8) No recalls } \\
\text { (9) High clinical } \\
\text { efficiency } \\
\text { (c) No sampling } \\
\text { errors }\end{array}$ & $\begin{array}{l}\text { 2. Testing not in } \\
\text { blood } \\
\text { establishments } \\
\text { Staff training and } \\
\text { lab devices } \\
\text { necessary in } \\
\text { hospitals }\end{array}$ \\
\hline
\end{tabular}

tests. Another disadvantage is the additional laboratory equipment. Handling of tests on clinical wards might be more critical than under the controlled good manufactured praxis (GMP) conditions in blood establishments. Systems that use RFID technology will be much easier to handle because only stored data on the chip must be read. However, current field studies are eagerly awaited to expand our experience with those technologies. Finally, figure 2 summarises the advantages and disadvantages of the culture systems, rapid detection systems, and bedside tests. As shown in figure 2, all of the screening strategies have advantages as well as disadvantages and demonstrate that bacterial screening of blood compo- nents is more complex than testing for transfusion-transmitted viruses. All of the existing strategies can cover an intermediate time period until implementation of highly efficient technologies that can inactivate pathogens universally in all blood components. Until then, improvements in bacterial screening systems will be helpful to reduce the risk of transfusion-transmitted bacterial infections.

\section{Disclosure Statement}

The authors declared no conflicts of interest.

\section{References}

1 Hourfar MK, Jork C, Schottstedt V, Weber-Schehl M, Brixner V, Busch MP, Geusendam G, Gubbe K, Mahnhardt C, Mayr-Wohlfart U, Pichl L, Roth WK, Schmidt M, Seifried E, Wright DJ: Experience of german red cross blood donor services with nucleic acid testing: results of screening more than 30 million blood donations for human immunodeficiency virus- 1 , hepatitis $\mathrm{C}$ virus, and hepatitis $\mathrm{B}$ virus. Transfusion 2008;48:1558-1566.

$\checkmark 2$ Chapman CE, Stainsby D, Jones H, Love E, Massey E, Win N, Navarrete C, Lucas G, Soni N, Morgan C, Choo L, Cohen H, Williamson LM: Ten years of hemovigilance reports of transfusion-related acute lung injury in the United Kingdom and the impact of preferential use of male donor plasma. Transfusion 2009;49:440-452.

>3 Montag T, Nicol SB, Schurig U, Heiden M, Huber H, Sanzenbacher R, Flory E, Schwanig M, Schneider CK: Microbial safety of cell based medicinal products - what can we learn from cellular blood components? Clin Chem Lab Med 2008;46:963965.

4 Montag T: Strategies of bacteria screening in cellular blood components. Clin Chem Lab Med 2008;46: 926-932.

5 Walther-Wenke G, Wirsing von Konig CH, Daubener W, Heiden M, Hoch J, Hornei B, Volkers P: Monitoring bacterial contamination of blood components in Germany: effect of contamination reduction measures. Vox Sang;100:359-366.
6 Walther-Wenke G, Schrezenmeier H, Deitenbeck R, Geis G, Burkhart J, Hochsmann B, Sireis W, Schmidt M, Seifried E, Gebauer W, Liebscher UM, Weinauer F, Muller TH: Screening of platelet concentrates for bacterial contamination: spectrum of bacteria detected, proportionof transfused units, and clinical follow-up. Ann Hematol 2009;89:83-91.

7 Walther-Wenke G: Incidence of bacterial transmission and transfusion reactions by blood components. Clin Chem Lab Med 2008;46:919-925.

8 Pietersz RN, Engelfriet CP, Reesink HW, Wood EM, Winzar S, Keller AJ, Wilson JT, Henn G, Mayr WR, Ramirez-Arcos S, Goldman M, Georgsen J, Morel P, Herve P, Andeu G, Assal A, Seifried E, Schmidt M, Foley M, Doherty C, Coakley P, Salami A, Cadden E, Murphy WG, Satake M, de Korte D, Bosnes V, Kjeldsen-Kragh J, McDonald C, Brecher ME, Yomtovian R, AuBuchon JP: Detection of bacterial contamination of platelet concentrates. Vox Sang 2007;93:260-277.

9 Brecher ME, Hay SN, Rose AD, Rothenberg SJ: Evaluation of BacT/ALERT plastic culture bottles for use in testing pooled whole blood-derived leukoreduced platelet-rich plasma platelets with a single contaminated unit. Transfusion 2005:45:1512-1517.

10 Brecher ME, Hay SN, Rothenberg SJ: Validation of BacT/ALERT plastic culture bottles for use in testing of whole-blood-derived leukoreduced platelet-rich-plasma-derived platelets. Transfusion 2004;44:1174-1178.

11 Hundhausen T, Muller TH: False-positive alarms for bacterial screening of platelet concentrates with BacT/ALERT new-generation plastic bottles: a multicenter pilot study. Transfusion 2005;45:1267-1274.
12 Larsen CP, Ezligini F, Hermansen NO, KjeldsenKragh J: Six years' experience of using the BacT/ ALERT system to screen all platelet concentrates, and additional testing of outdated platelet concentrates to estimate the frequency of false-negative results. Vox Sang 2005;88:93-97.

13 McDonald CP, Rogers A, Cox M, Smith R, Roy A, Robbins S, Hartley S, Barbara JA, Rothenberg S, Stutzman L, Widders G: Evaluation of the $3 \mathrm{~d}$ BacT/ALERT automated culture system for the detection of microbial contamination of platelet

concentrates. Transfus Med 2002;12:303-309.
14 McDonald CP, Roy A, Lowe P, Robbins S, Hartley S, Barbara JA: Evaluation of the BacT/ALERT automated blood culture system for detecting bacteria and measuring their growth kinetics in leucodepleted and non-leucodepleted platelet concentrates. Vox Sang 2001:81:154-160.

15 Koopman MM, van't Ende E, Lieshout-Krikke R, Marcelis J, Smid WM, de Korte D: Bacterial screening of platelet concentrates: Results of 2 years active surveillance of transfused positive cultured units released as negative to date. Vox Sang 2009;97:355-357.

16 Muller TH, Mohr H, Montag T: Methods for the detection of bacterial contamination in blood products. Clin Chem Lab Med 2008;46:933-946.

17 Nussbaumer W, Allersdorfer D, Grabmer C, Rheinschmidt M, Lin L, Schonitzer D, Lass-Florl C: Prevention of transfusion of platelet components contaminated with low levels of bacteria: a comparison of bacteria culture and pathogen inactivation methods. Transfusion 2007;47:1125-1133. 
18 Schrezenmeier H, Walther-Wenke G, Muller TH, Weinauer F, Younis A, Holland-Letz T, Geis G, Asmus J, Bauerfeind U, Burkhart J, Deitenbeck R, Forstemann E, Gebauer W, Hochsmann B, Karakassopoulos A, Liebscher UM, Sanger W, Schmid M, Schunter F, Sireis W, Seifried E: Bacterial contamination of platelet concentrates: results of a prospective multicenter study comparing pooled whole blood-derived platelets and apheresis platelets. Transfusion 2007;47:644-652

19 Savini V, Balbinot A, Giancola R, Quaglietta A, Accorsi P, D'Antonio D, Iacone A: Comparison between the Bactec 9240 and the Pall eBDS system for detection of bacterial platelet concentrate contamination. Transfusion 2009;49:1217-1223.

-20 Riedel S, Junkins A, Stamper PD, Cress G, Widness JA, Doern GV: Comparison of the Bactec 9240 and BacT/ALERT blood culture systems for evaluation of placental cord blood for transfusion in neonates. J Clin Microbiol 2009;47:1645-1649.

-21 Riedel S, Siwek G, Beekmann SE, Richter SS, Raife T, Doern GV: Comparison of the Bactec 9240 and BacT/ALERT blood culture systems for detection of bacterial contamination in platelet concentrates. J Clin Microbiol 2006;44:2262-2264.

22 Schmidt M, Karakassopoulos A, Burkhart J, Deitenbeck R, Asmus J, Muller TH, Weinauer F, Seifried E, Walther-Wenke G: Comparison of three bacterial detection methods under routine conditions. Vox Sang 2007;92:15-21.

23 McDonald CP, Pearce S, Wilkins K, Colvin J, Robbins S, Colley L, Taylor J, Barbara JA: Pall eBDS: an enhanced bacterial detection system for screening platelet concentrates. Transfus Med 2005;15:259-268.

24 Holme S, McAlister MB, Ortolano GA, Chong C, Cortus MA, Jacobs MR, Yomtovian R, Freundlich LF, Wenz B: Enhancement of a culture-based bacterial detection system (eBDS) for platelet products based on measurement of oxygen consumption. Transfusion 2005;45:984-993.

-25 Dreier J, Stormer M, Kleesiek K: Real-time polymerase chain reaction in transfusion medicine: applications for detection of bacterial contamination in blood products. Transfus Med Rev 2007;21:237-254.

26 Nadkarni MA, Martin FE, Jacques NA, Hunter N: Determination of bacterial load by real-time PCR using a broad-range (universal) probe and primers set. Microbiology 2002;148:257-266.

-27 Petershofen EK, Fislage R, Faber R, Schmidt H, Roth WK, Seifried E: Detection of nucleic acid sequences from bacterial species with molecular genetic methods. Transfus Sci 2000;23:21-27.

28 Mohammadi T, Pietersz RN, VandenbrouckeGrauls CM, Savelkoul PH, Reesink HW: Detection of bacteria in platelet concentrates: comparison of broad-range real-time 16s rDNA polymerase chain reaction and automated culturing. Transfusion 2005;45:731-736.

29 Mohr H, Lambrecht B, Bayer A, Spengler HP, Nicol SB, Montag T, Muller TH: Basics of flow cytometry-based sterility testing of platelet concen trates. Transfusion 2006;46:41-49.

>30 Schmidt M, Hourfar MK, Nicol SB, Spengler HP, Montag T, Seifried E: FACS technology used in a new rapid bacterial detection method. Transfus Med 2006;16:355-361.

31 Schmidt M, Weis C, Heck J, Montag T, Nicol SB, Hourfar MK, Schaefer V, Sireis W, Roth WK, Seifried E: Optimized scansystem platelet kit for bacterial detection with enhanced sensitivity: detection within 24 h after spiking. Vox Sang 2005;89:135139.

Implementation of Bacterial Detection

Methods into Blood Donor Screening
McDonald CP, Colvin J, Robbins S, Barbara JA: Use of a solid-phase fluorescent cytometric technique for the detection of bacteria in platelet concentrates. Transfus Med 2005;15:175-183.

33 Jacobs MR, Bajaksouzian S, Windau A, Palavecino EL, Yomtovian R: Evaluation of the Scansystem method for detection of bacterially contaminated platelets. Transfusion 2005;45:265-269.

34 Ribault S, Faucon A, Grave L, Nannini P, Faure IB: Detection of bacteria in red blood cell concentrates by the Scansystem method. J Clin Microbiol 2005;43:2251-2255.

35 Dreier J, Vollmer T, Kleesiek K: Novel flow cytometry-based screening for bacterial contamination of donor platelet preparations compared with other rapid screening methods. Clin Chem 2009;55:1492-1502.

36 Motoyama Y, Yamaguchi N, Matsumoto M, Kagami N, Tani Y, Satake M, Nasu M: Rapid and sensitive detection of viable bacteria in contaminated platelet concentrates using a newly developed bioimaging system. Transfusion 2008;48:2364-2369.

37 Fleming P: Abstract Presentations from the AABB Annual Meeting and TXPO (Reissued December 2008). Scientific section. Transfusion 2008;48(suppl 1):1A-241A.

38 Brecher ME, Hay SN: Bacterial contamination of blood components. Clin Microbiol Rev 2005;18:195-204.

39 Yomtovian R: Bacterial contamination of blood: lessons from the past and road map for the future. Transfusion 2004;44:450-460.

40 Abstract Presentations from the AABB Annual Meeting. Scientific section. Transfusion 2004;44 (suppl 1):1A-141A.

41 Knels R, Ashford P, Bidet F, Bocker W, Briggs L, Bruce P, Csore M, Distler P, Gutierrez A, Henderson I, Hohberger C, Holcombe J, Holmberg J, Hulleman R, Marcel B, Messenger P, Mun I, Roberts S, Sandler G, Veeramani R, Wray B: Guidelines for the use of RFID technology in transfusion medicine. Vox Sang;98(suppl 2):1-24

42 Briggs L, Davis R, Gutierrez A, Kopetsky M, Young K, Veeramani R: RFID in the blood supply chain - increasing productivity, quality and patient safety. J Healthc Inf Manag 2009;23:54-63.

43 Jiang M, Xing B, Sun Z, Fu P, Chen H, Chen M, Deng P, Wang G, Xu Y, Wang Y: A dynamic blood information management system based on RFID. Conf Proc IEEE Eng Med Biol Soc 2005;1:546549

44 Lusky K: Adding RFID layer to blood safety loop. CAP Today 2005;19:1, 46, 48 passim.

45 te Boekhorst PA, Beckers EA, Vos MC, Vermeij $\mathrm{H}$, van Rhenen DJ: Clinical significance of bacteriologic screening in platelet concentrates. Transfusion 2005;45:514-519.

46 Eder AF, Kennedy JM, Dy BA, Notari EP, Weiss JW, Fang CT, Wagner S, Dodd RY, Benjamin RJ: Bacterial screening of apheresis platelets and the residual risk of septic transfusion reactions: the American Red Cross experience (2004-2006). Transfusion 2007;47:1134-1142.

47 Fang CT, Chambers LA, Kennedy J, Strupp A, Fucci MC, Janas JA, Tang Y, Hapip CA, Lawrence TB, Dodd RY: Detection of bacterial contamination in apheresis platelet products: American Red Cross experience, 2004. Transfusion 2005;45:1845-1852.

48 Sireis W, Ruster B, Daiss C, Hourfar MK, Capalbo G, Pfeiffer HU, Janetzko K, Goebel M, Kempf VA, Seifried E, Schmidt M: Extension of platelet shelf life from 4 to 5 days by implementation of a new screening strategy in Germany. Vox Sang 2011; doi: 10.1111/j.1423-0410.2011.01485.x.
49 Feng P, Keasler SP, Hill WE: Direct identification of Yersinia enterocolitica in blood by polymerase chain reaction amplification. Transfusion 1992;32:850-854.

50 Mohammadi T, Reesink HW, VandenbrouckeGrauls CM, Savelkoul PH: Optimization of realtime PCR assay for rapid and sensitive detection of eubacterial 16s ribosomal DNA in platelet concentrates. J Clin Microbiol 2003;41:4796-4798.

51 Mohammadi T, Reesink HW, VandenbrouckeGrauls CM, Savelkoul PH: Removal of contaminating DNA from commercial nucleic acid extraction kit reagents. J Microbiol Methods 2005;61: 285-288.

52 Dreier J, Stormer M, Kleesiek K: Two novel realtime reverse transcriptase PCR assays for rapid detection of bacterial contamination in platelet concentrates. J Clin Microbiol 2004;42:4759-4764.

53 Harris KA, Hartley JC: Development of broadrange 16s rDNA PCR for use in the routine diagnostic clinical microbiology service. J Med Microbiol 2003;52:685-691.

54 Schmidt M, Hourfar MK, Nicol SB, Wahl A, Heck $\mathrm{J}$, Weis C, Tonn T, Spengler HP, Montag T, Seifried E, Roth WK: A comparison of three rapid bacterial detection methods under simulated reallife conditions. Transfusion 2006;46:1367-1373.

55 Corless CE, Guiver M, Borrow R, Edwards-Jones V, Kaczmarski EB, Fox AJ: Contamination and sensitivity issues with a real-time universal $16 \mathrm{~s}$ rRNA PCR. J Clin Microbiol 2000;38:1747-1752.

56 Hourfar MK, Schmidt M, Seifried E, Roth WK: Evaluation of an automated high-volume extraction method for viral nucleic acids in comparison to a manual procedure with preceding enrichment. Vox Sang 2005;89:71-76.

57 Stormer M, Kleesiek K, Dreier J: High-volume extraction of nucleic acids by magnetic bead technology for ultrasensitive detection of bacteria in blood components. Clin Chem 2007;53:104-110.

58 Mohr H, Lambrecht B, Bayer A, Spengler HP, Nicol SB, Montag T, Muller TH: Sterility testing of platelet concentrates prepared from deliberately infected blood donations. Transfusion 2006;46:486491.

59 Vollmer T, Engemann J, Kleesiek K, Dreier J: Bacterial screening by flow cytometry offers potential for extension of platelet storage: results of 14 months of active surveillance. Transfus Med 2011;21:175-182.

60 Yomtovian R, Tomasulo P, Jacobs MR: Platelet bacterial contamination: assessing progress and identifying quandaries in a rapidly evolving field. Transfusion 2007;47:1340-1346.

61 Yomtovian RA, Palavecino EL, Dysktra AH, Downes KA, Morrissey AM, Bajaksouzian S, Pokorny MA, Lazarus HM, Jacobs MR: Evolution of surveillance methods for detection of bacterial contamination of platelets in a university hospital, 1991 through 2004. Transfusion 2006;46:719-730.

62 Schmidt M: Abstract Presentations from the AABB Annual Meeting and TXPO (Reissued December 2008). Scientific section. Transfusion 2008;48(suppl 1):1A-241A

63 Silva MA, Gregory KR, Carr-Greer MA, Holmberg JA, Kuehnert MJ, Brecher ME: Summary of the AABB interorganizational task force on bacterial contamination of platelets: fall 2004 impact survey. Transfusion 2006;46:636-641.

64 Chen CL, Yu JC, Holme S, Jacobs MR, Yomtovian $\mathrm{R}$, McDonald CP: Detection of bacteria in stored red cell products using a culture-based bacterial detection system. Transfusion 2008;48:1550-1557. 